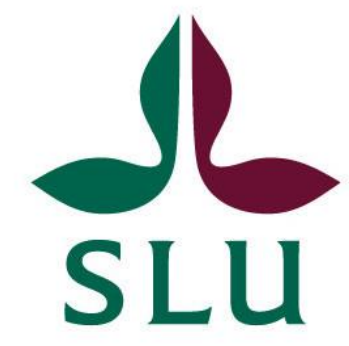

This is an author produced version of a paper published in Journal of Agricultural Science.

This paper has been peer-reviewed but may not include the final layout and proof-corrections by the publisher.

Citation for the published paper:

Souza, J. M., Souza, J. C. S. M., Sousa, D. O., Del Valle, T. A., Ghizzi, L. G., Alcântara, A. H. D., Mesquita, L. G., Sousa, R. L. M., Bueno, I. C. S. and Balieiro, J. C. C. (2021) "The effects of compound treatment of Aspergillus oryzae and fibrolytic enzyme on in vitro degradation, gas production and fermentative profile of maize silage and sugarcane silage," The Journal of Agricultural Science. Cambridge University Press, 159(1-2), pp. 147-158. doi: 10.1017/S002185962100037X.

Published with permission from: Cambridge University Press

This manuscript version is made available under the CC-BY-NC-ND 4.0 license http://creativecommons.org/licenses/by-nc-nd/4.0/

This publication is openly available through SLU publication database, http://urn.kb.se/resolve?urn= urn:nbn:se:slu:epsilon-p-111968 


\title{
The effects of compound treatment of Aspergillus oryzae and fibrolytic enzyme on in vitro degradation, gas production and fermentative profile of maize silage and sugarcane silage
}

\author{
J. M. Souza1', J. C. S. M. Souza1, D. O. Sousa², T. A. Del Valle³, L. G. Ghizzi', \\ A. H. D. Alcântara', L. G. Mesquita ${ }^{1}$, R. L. M. Sousa ${ }^{4}$, I. C. S. Bueno ${ }^{4}$ \\ and J. C. C. Balieiro ${ }^{1}$

\begin{abstract}
${ }^{1}$ Faculty of Veterinary Medicine and Animal Science, Department of Animal Nutrition and Animal Production, University of São Paulo, Pirassununga 13635-900, Brazil; ${ }^{2}$ Department of Animal Environment and Health, Swedish University of Agricultural Sciences, Skara 532 23, Sweden; ${ }^{3}$ Federal University of Pampa, Itaqui 96460-000, Brazil and ${ }^{4}$ Faculty of Animal Science and Food Engineering, Department of Animal Science, University of São Paulo, Pirassununga 13635-900, Brazil
\end{abstract}

Keywords:

Additives; direct-fed microbials; fibre digestibility; in vitro bioassay; ruminants

Author for correspondence: J. M. Souza,

Email: souza.jm@gmail.com

\begin{abstract}
The present study was conducted to evaluate the effect of a live culture of Aspergillus oryzae (A; CCT4359) and fibrolytic enzyme (E; Fibrozyme Alltech Inc.) on fibre digestibility by a gas production bioassay and in vitro degradation of maize silage and sugarcane silage. A completely randomized design trial was performed to evaluate: A doses $(0,20,60$ and $100 \mathrm{mg} / \mathrm{l}), \mathrm{E}$ doses $(0,160$, 320 and $480 \mathrm{mg} / \mathrm{l})$ and roughage source (R; maize and sugarcane silage) in a $4 \times 4 \times 2$ factorial arrangement. The inclusion of increasing doses of $\mathrm{A}$ and $\mathrm{E}$ increased dry matter and neutral detergent fibre in vitro digestibility linearly, but for $\mathrm{E}$ this effect occurred only in maize silage. There was a linear increase in the potential for gas production at the highest dose of A only in sugarcane silage, with no effect on lag time $(\mathrm{L})$. Increasing doses of $\mathrm{E}$ increased the volume of gases produced linearly, and a trend of linear reduction of L, regardless of the roughage. There was a linear reduction in ammonia-nitrogen concentration in response to increasing doses of $\mathrm{A}$ and $\mathrm{E}$, and an increase in acetic acid concentration at the highest dose of A, regardless of roughage. The additives had no synergistic effect on gas production and digestibility, but were efficient in altering the fermentative pattern, demonstrating the potential to increase fibre degradation.
\end{abstract}

\section{Introduction}

The fibre of ruminant diets promotes ruminal health via stimulation of rumination and tamponade, as well as it is used as a substrate for ruminal fermentation (Mertens, 2000). Feed additive strategies have been evaluated to improve fibre digestibility and feed efficiency. Exogenous fibrolytic enzyme increases the dry matter (DM) and neutral detergent fibre(NDF) in vitro degradation (Gandra et al., 2017; Zayed et al., 2020), fermentative kinetics (Elghandour et al., 2016) and beef cattle average daily gain (Tirado-González et al., 2018). However, the efficiency of exogenous enzyme is highly variable (Meale et al., 2014; Abid et al., 2019). The beneficial impact of the exogenous fibrolytic enzymes on fibre digestibility depends on several factors, such as the basal diet composition, enzymatic preparation, methods of application and doses (Mendoza et al., 2014; Elghandour et al., 2016), ruminal retention time and $\mathrm{pH}$, which affects the ruminal activity and enzymatic stability (Meale et al., 2014).

Microbial feed additive, such as the fungus Aspergillus oryzae, may enhance the utilization of fibre through the improvement of microbial activity (Giraldo et al., 2008; Sun et al., 2017), due to the mechanical action on the fibre, increasing bacterial access and adherence of microorganisms to fibre fraction, increasing the fibre digestibility (Sosa et al., 2011; Sun et al., 2014). The use of $A$. oryzae increases the feed intake (Latif et al., 2014), average daily gain (Tricarico et al., 2007) and milk yield (Kim et al., 2006; Sun et al., 2017).

Both additives, fibrolytic enzyme and $A$. oryzae, have the potential to modulate rumen fermentation and increase fibre digestibility. To the authors' knowledge, there are no studies evaluating the effect of these additives combination on in vitro digestibility and gas production. It was hypothesized that $A$. oryzae and exogenous fibrolytic enzyme would synergistically improve gas production and in vitro degradation of different forages. The present study was conducted to evaluate the effect of $A$. oryzae and fibrolytic enzyme levels on maize and sugarcane silages degradation, fermentative profile and in vitro gas production. 


\section{Material and methods}

All experimental procedures were in agreement with the Guide for Care and Use of Agricultural Animals in Agricultural Research and Teaching (FASS, 1999), with all animal procedures approved by the University of São Paulo Animal Bioethics Committee ( protocol number 7551070817). The experiment was carried out at the Ruminal Fermentation Laboratory (LFR), in the Faculty of Animal Science and Food Engineering (FZEA), the University of São Paulo (Pirassununga, SP, Brazil, 21 ${ }^{\circ} 57^{\prime} \mathrm{S}, 47^{\circ} 27^{\prime} \mathrm{E}, 630 \mathrm{~m}$ a.s.1.).

\section{Treatments and experimental design}

In vitro gas production bioassay was performed as a completely randomized design with three repetitions (inoculum) per treatments. Treatments were obtained from a $4 \times 4 \times 2$ factorial arrangement,in which were evaluated: (1) doses of $A$. oryzae (A): 0, 20, 60 and $100 \mathrm{mg} / \mathrm{l}$ (A0, A1, A2 and A3, respectively); (2) fibrolytic enzyme (E, Fibrozyme Alltech Inc., Nicholasville, KY, USA): 0, 160, 320 and $480 \mathrm{mg} / \mathrm{l}$ (E0, E1, E2 and E3, respectively); and (3) roughage: maize and sugarcane silage (Table 1); totalling 32 treatments.

Aspergillus oryzae (CCT 4359) was cultivated in Petri plates with Sabouraud dextrose agar 4\% (Acumidia) and kept in a BOD Incubator (MarqLabor) at $28^{\circ} \mathrm{C}$ for fungal growth. Then, a morphological analysis was performed by microculture to confirm the cultivated fungus. Large-scale production was carried out at the Department of Food Engineering and Technology of São Paulo State University (UNESP, São José do Rio Preto/SP Brazil). The fungus was grown in Erlenmeyer (1 litre) containing Sabouraud dextrose agar $4 \%$ (Acumidia) and incubated at $28^{\circ} \mathrm{C}$ to increase the number of viable spores. Subsequently, the vegetative portion along with the spores was collected and incorporated into a nutrient solution containing $\left(\mathrm{NH}_{4}\right)_{2} \mathrm{SO}_{4}, \mathrm{MgSO}_{4} .7 \mathrm{H}_{2} \mathrm{O}, \mathrm{KH}_{2} \mathrm{PO}_{4}$, $\mathrm{FeSO}_{4} .7 \mathrm{H}_{2} \mathrm{O}, \mathrm{ZnSO}_{4}$, e $\mathrm{MnSO}_{4}$. This solution was incorporated into a mixture of sugarcane bagasse and wheat bran (3:1 ratio) and transferred to a bioreactor. The bioreactor was composed of ten jacketed modules, previously autoclaved, made of aluminium. Each module was $20 \mathrm{~cm}$ in diameter and $20 \mathrm{~cm}$ in length (wide bioreactor), vertically connected. The tem- perature was monitored at different heights with T-type thermo- couples placed between consecutive modules. Water was circulated through the jacket in order to keep the wall temperatureconstant (Cunha et al., 2020; Frassatto et al., 2020).

After 7 days, the bioreactor was opened and a sample was collected for colony-forming unit (CFU) counting, and all fermented content was removed and frozen $\left(-20^{\circ} \mathrm{C}\right)$. The culture medium (sugarcane bagasse and wheat bran) overgrown with fungi $A$. oryzae was preserved by lyophilization. Freeze-drying was performed with a lyophilizer (Semi-Industrial Freeze Dryer LJI010) at an external manifold with a pressure of 0.2 mbar for $20 \mathrm{~h}$ (Grzegorczyk et al., 2018). The CFU counting was $6 \times 10^{8} / \mathrm{g}$ of dried A. oryzae.

The doses of the additives used in the present study were defined considering a daily supplementation for cattle with a ruminal capacity of 50 litres. Thus, the doses of $A$. oryzae were equivalent to $0,1,3$ and $5 \mathrm{~g}$, and for fibrolytic enzyme were 0 , 8,16 and $24 \mathrm{~g}$.

\section{Animals, substrate and inoculum preparation}

Six Holstein cows (Bos taurus taurus) were used as inoculum donors for in vitro assays. Animals were cannulated, kept in free- stall pens with free access to water, receiving a diet with $600 \mathrm{~g} / \mathrm{kg}$ maize silage and $400 \mathrm{~g} / \mathrm{kg}$ concentrate for 21 days.

At 6:00 h, before the first feeding, samples of the solid and liquid phases of the ruminal content of each animal were collected separately and individually. The ruminal content was manually filtered with cotton cloth, to obtain solid and liquid fractions. Then, samples of the solid phase were stored in plastic bags,kept in a heated box at $39^{\circ} \mathrm{C}$. The liquid phase was stored in prewarmed thermal bottles, previously flushed with $\mathrm{CO}_{2}$. After sampling, the material was immediately sent to the laboratory. One inoculum was prepared with two donor animals, totalling three repetitions. For each inoculum, equal proportions of liquid and solid were homogenized in a blender for $10 \mathrm{~s}$, previously inflated with $\mathrm{CO}_{2}$, and filtered through three layers of cotton cloth, according to Bueno et al. (2005). The inocula were kept in an in vitro incubator at $39^{\circ} \mathrm{C}\left(\mathrm{TE}-150\right.$ Tecnal ${ }^{\circledR}$, Piracicaba, Brazil) and constantly saturated with $\mathrm{CO}_{2}$ until use.

\section{In vitro bioassay and treatments}

The fermentative kinetics bioassays were performed according to Theodorou et al. (1994) method, adapted by Mauricio et al.(1999) and Bueno et al. (2005). Two gas production bioassayswere performed simultaneously: a short incubation test $(24 \mathrm{~h})$ defined as a methanogenesis bioassay; and another long-term incu-bation period $(96 \mathrm{~h})$ defined as fermentative kinetics bioassay. Blanks were used for each inoculum and all samples were used in triplicate. For the methanogenesis bioassay, approximately $500 \mathrm{mg}$ of ground sample $(1 \mathrm{~mm}$ sieve) of roughages were weighed andplaced in bags (Ankom, F57), and then placed in fermentationflasks (160 ml). The doses of $\mathrm{A}$ and $\mathrm{E}$ were added within $100 \mu$ lof saline solution per vial, in order to standardize the headspace

for gas production in all vials.

After the additives were added to the vials, $25 \mathrm{ml}$ of the ruminal inoculum was diluted with $75 \mathrm{ml}$ of nutrient solution (Menke's buffered medium) as described by Onodera andHenderson (1980), continuously saturated with $\mathrm{CO}_{2}$ and kept at $39^{\circ} \mathrm{C}$ until use, and immediately transferred to each vial. All vials were sealed with $20 \mathrm{~mm}$ butyl rubber septum stoppers (Bellco Glass, Vineland, NY, USA), manually shaken, and kept in a forced-ventilation oven at $39^{\circ} \mathrm{C}$.

After incubation for 4, 8, 12, 16 and $24 \mathrm{~h}$, the headspace gas pressure was measured with a pressure transducer and a datalogger (PressDATA 800®, LFR, FZEA-USP, Pirassununga, Brazil), and the values obtained were used to estimate the gas volumes produced, employing the equation defined for the test laboratory conditions: $V=p \times 6.4278$, where $V$ is gas volume $(\mathrm{ml})$ and $p$ is gas pressure ( psi) (Santos et al., 2020). After each pressure reading, a $2 \mathrm{ml} \mathrm{sample} \mathrm{of} \mathrm{the} \mathrm{gases} \mathrm{produced} \mathrm{inside} \mathrm{the} \mathrm{vials} \mathrm{was} \mathrm{col-}$ lected with a syringe to measure the methane concentration. Samples were stored in $10 \mathrm{ml}$ Vacutainer tubes, and cooled until quantitative analyses. After measuring the pressure and collecting the gas samples, the internal pressure of each vial was released at each incubation period with the aid of a syringe, equalizing the vial and atmosphere pressures, in order to not overestimate the gas production of subsequent collection. Then, the vials were sha-ken for content homogenization before returning to the incubator. At the end of the bioassay $(24 \mathrm{~h})$, the vials were opened and bags removed for the determination of in vitro degradation of DM (IVDMD24) and NDF after $24 \mathrm{~h}$ of incubation (IVNDF24).

For the fermentative kinetics bioassay, $1 \mathrm{~g}$ of ground sample (1 $\mathrm{mm}$ sieve) was placed in bags (Ankom, F57), and transferred to 
Table 1. Chemical composition of roughages used as substrates in in vitro degradability and gas production bioassay

\begin{tabular}{lcc}
\hline Ítem $^{\mathrm{a}}$ & Maize silage & Sugarcane silage \\
\hline Chemical composition, g/kg DM & & \\
\hline Dry matter, g/kg as-fed & 318 & 300 \\
\hline Organic matter & 948 & 949 \\
\hline Neutral detergent fibre (NDF) & 486 & 516 \\
\hline Acid detergent fibre (ADF) & 306 & 472 \\
\hline Non-fibre carbohydrate (NFC) & 352 & 389 \\
\hline Crude protein (CP) & 73.9 & 31.0 \\
\hline Acid detergent lignin (ADL) & 49.4 & 53.7 \\
\hline Ether extract (EE) & 36.4 & 12.9 \\
\hline
\end{tabular}

DM, dry matter

aNFC $=1000-(\mathrm{NDF}+\mathrm{CP}+\mathrm{EE}+$ ash) (Balieiro Neto et al., 2009).

fermentation flasks $(160 \mathrm{ml})$, submitted to the same treatments used in the methanogenesis bioassay. Then, $10 \mathrm{ml}$ of the inoculum was diluted in $90 \mathrm{ml}$ of nutrient solution, following the procedures described for the methanogenesis bioassay. The internal gas pressure in the flasks was measured after incubation for 4 , $8,12,18,24,30,36,48,60,72$ and $96 \mathrm{~h}$, and the data were transformed into volume employing the following equation: $V=p \times$ 4.6788 (Santos et al., 2020).

At the end of the bioassay ( $96 \mathrm{~h}$ ), each vial was opened and the liquid phase was sampled $(2 \mathrm{ml})$ and transferred to a vessel containing $0.4 \mathrm{ml}$ of formic acid for the determination of short-chain fatty acids (SCFA) and $\mathrm{N}$-ammoniacal concentration $\left(\mathrm{N}-\mathrm{NH}_{3}\right)$. The bags were also removed from the bottles for the determination of in vitro digestibility of DM (IVDMD96) and NDF after $24 \mathrm{~h}$ of incubation (IVNDF96).

\section{Laboratory analysis and procedures}

The roughage samples were characterized for their chemical composition according to AOAC (2000): DM content (ID 950.15), ash (ID 942.05), crude protein (ID 984.13), ether extract (ID 920.39). The NDF (using amylase, without sodium sulphite) and acid detergent fibre analysis was performed according to Mertens (2002). Lignin analysis was performed according to Van Soest and Robertson (1985), whose measurement occurred after $12 \mathrm{M}$ sulphuric acid cellulose hydrolysis in the sample residue.

The samples collected in the methanogenesis bioassay were submitted to methane measurement by gas chromatography (Model 2014; Shimadzu, Tokyo), according to the methodology described by Sallam et al. (2010), representing a cumulative 24 $\mathrm{h}$ of fermentation. For $\mathrm{NH}_{3}-\mathrm{N}$ assay, $2 \mathrm{ml}$ of supernatant was mixed with $1 \mathrm{ml}$ of $1 \mathrm{~N} \mathrm{H}_{2} \mathrm{SO}_{4}$, and analysis was performed using the phenol-hypochlorite method (Broderick and Kang, 1980). The concentration of SCFA was quantified by gas chroma-tography, with column Stabilwax, according to Erwin et al. (1961), adapted by Getachew et al. (2002).

For in vitro DM degradation (IVDMD) and in vitro NDF degradation (IVNDFD) evaluation, the bags were washed in running water until fully bleached, and transferred to a forced ventilation oven at $55^{\circ} \mathrm{C}$ and kept for $72 \mathrm{~h}$. Sequentially, they were dried in a non-ventilated oven at $105^{\circ} \mathrm{C}$ for $45 \mathrm{~min}$. They were then placed in a desiccator and weighed to obtain undigested DM.
Subsequently, the bags were destined for NDF analysis in a fibre analyser (Ankom $\left.{ }^{\circledR}\right)$ at $90^{\circ} \mathrm{C}$ for $1 \mathrm{~h}$ and sequentially washed with hot water and acetone, dried at $60^{\circ} \mathrm{C}$ for $72 \mathrm{~h}$ and then weighed, according to the previous methodology (Detmann et al., 2001; Casali et al., 2008).

The cumulative gas production curves were adjusted by using the model proposed by France et al. (1993):

$$
\left.V_{\mathrm{t}}=V_{\mathrm{f}} \times 1-\exp ^{(-b \times(t-L)-c \times({ } t-{ }{ })}\right\}
$$

where $V_{\mathrm{t}}$ is the accumulated volume $(\mathrm{ml})$ of gases produced after the period of incubation, $V_{\mathrm{f}}$ is the final volume or maximum potential for gas production (asymptotic value; $\mathrm{ml} / \mathrm{g} \mathrm{DM}$ ), $b$ (1/ h) and $c(1 / 2 \mathrm{~h})$ are constant fractional rates, $L$ is lag time, and $t$ is the time (h) of incubation.

\section{Statistical analysis}

Data were analysed using SAS ${ }^{2} 9.4$ software (Statistical Analysis System Inst. Inc., Cary, NC) according to the following statistical model:

$$
\begin{aligned}
Y_{i j k l}= & m+E_{i}+R_{j}+A_{k}+E \times R_{i j}+E \times A_{i k}+R \times A_{j k}+E \times R \\
& \times A_{i j k}+\mathrm{e}_{i j k l}
\end{aligned}
$$

with $\mathrm{e}_{i j k l} \mathrm{~N}\left(0, \mathrm{~s}^{2}\right)$; where $Y_{i j k l}$ is the observed value of the dependent variable; $\mu$ is the general mean; $E_{i}$ is the fixed effect of the fibrolytic enzyme level $(i=1-4) ; R_{j}$ is the fixed effect of roughage ( $j=1$ and 2$) ; A_{k}$ is the fixed effect of $A$. oryzae level $(k=1-4)$; $E \times R_{i j}, E \times A_{i k}, R \times A_{j k}$ and $E \times R \times A_{i j k}$ are interaction effects between previously defined fixed effects; $e_{i j k l}$ is the random residual error $(l=1-3) ; N$ stands for Gaussian distribution; and $s^{2}$ is the residual variance. The degrees of freedom were adjusted using the Kenward-Roger method. Treatment averages were compared with the Fischer means test (LSD; $\alpha=0.05$ ). Interaction effects were declared at $P \leq 0.10$. Fibrolytic enzyme and $A$. oryzae level effects were decomposed using polynomial regression method.

\section{Results}

There was no $(P \geq 0.163)$ three-way interaction among fibrolytic enzyme, $A$. oryzae and roughage on studied variables (Table 2 ). There was no $(P \geq 0.131)$ two-way interaction among fibrolytic enzyme and $A$. oryzae. As we had a great roughage effect, the results obtained in response to doses of $A$. oryzae and fibrolytic enzyme were presented for each roughage separately.

For the digestibility parameters, it was observed that the inclusion of $A$. oryzae increased the IVDMD96 independently of the roughage $(P=0.031)$ and the effect was linear $(P=0.010)$ as the dose increased $(0.516,0.518,0.519$ and 0.526 for A0, A1, A2 and A3, respectively; Table 3). Likewise, increasing doses of $A$. oryzae promoted an increase in IVNDFD96, regardless of the roughage $(P=0.001)$, whose highest value was also for the highest dose of $A$. oryzae $(0.316,0.319,0.324$ and 0.335 for A0, A1, A2 and $\mathrm{A} 3$, respectively). For the degradability parameters obtained from the France model, there was a significant two-way interaction between $A$. oryzae and roughage $(P=0.010$; Table 3$)$, where the effect of treatment with increasing doses of $A$. oryzae over the $V_{\mathrm{f}}$ was different according to the roughage source. In sugarcane silage, A. oryzae increased the potential for gas 
Table 2. ANOVA table showing $P$ values (probability of non-significant effects) for the main treatment factors (roughage, fibrolytic enzyme and Aspergillus oryzae), and their interactions on digestibility, gas production parameters, total gas production, methanogenesis and fermentative profile

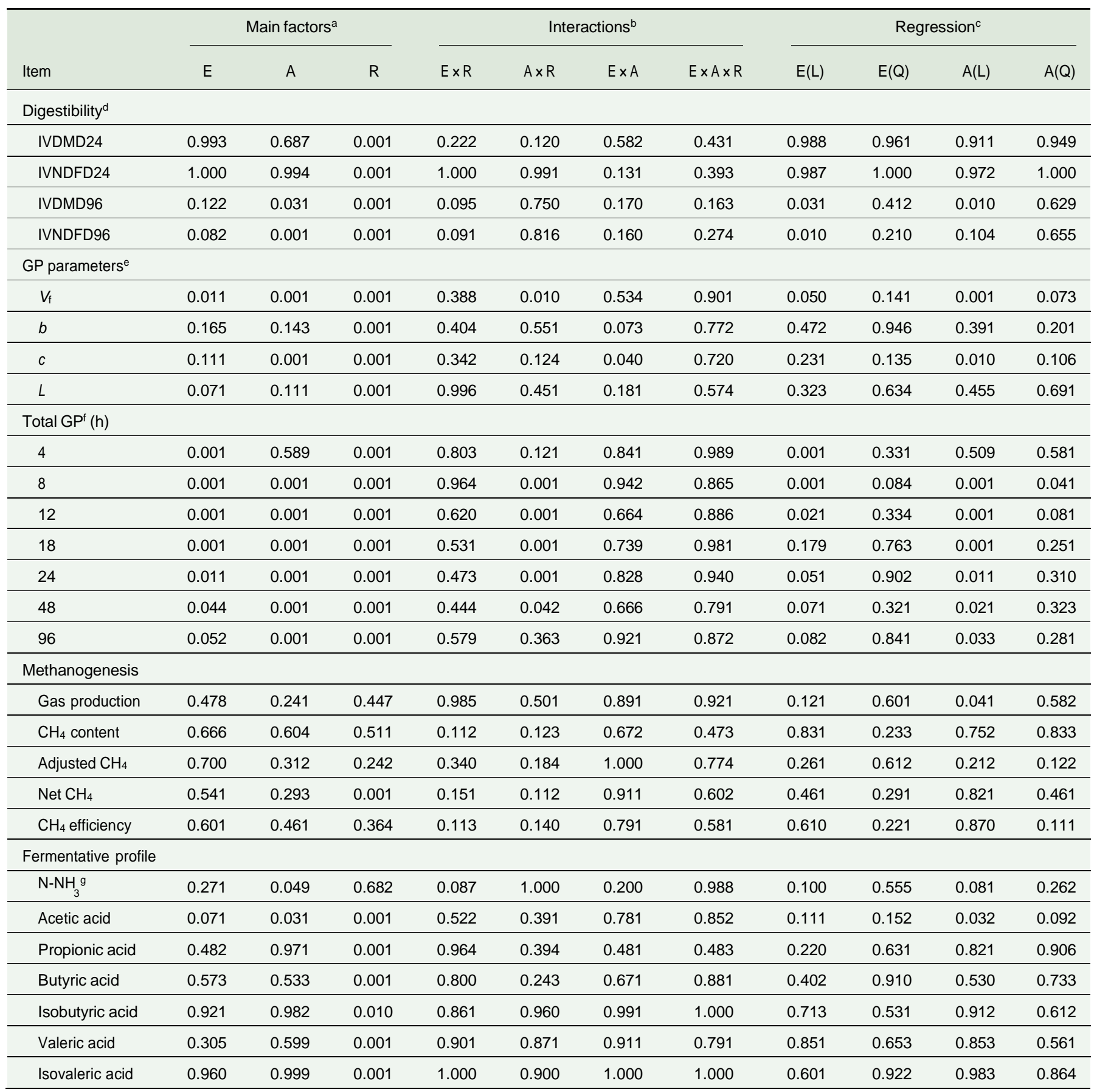

${ }^{a} E$ : fibrolytic enzyme; A: A. oryzae; R: roughage.

${ }^{\mathrm{b}}$ Two-way and three-way interaction among main factors.

'L: linear; Q: quadratic.

IVDMD: in vitro dry matter digestibility (24 and $96 \mathrm{~h}$ of incubation); IVNDFD: in vitro NDF digestibility (24 and $96 \mathrm{~h}$ ).

'Gas production parameters, obtained by the model of France et al. (1993); $V_{\mathrm{f}}$ : potential for gas production; $b$ and $c$ : constants fractional rates; $L$ : lag time.

${ }^{\mathrm{f}} \mathrm{C}$ umulative gas production at different times of incubation. $\mathrm{CH}_{4}$, methane.

${ }_{9} \mathrm{~N}-\mathrm{NH}_{3}$ : ammoniacal nitrogen.

production when compared to the control $(P=0.001)$, whereas the higher dosage resulted in the highest observed value.In maize silage, this effect was significant only in the highest dose of A. oryzae.

There was a trend of a significant two-way interaction among fibrolytic enzyme and roughage source for IVDMD96 and
IVDFD96 ( $P=0.095$ and $P=0.091$, respectively; Table 4), where the inclusion of fibrolytic enzyme increased the IVDMD96 only when the substrate was the maize silage, with no effect on sugarcane silage $(P=0.952)$. Similarly, there was an increase in IVNDFD96 only in response to the highest dose of fibrolytic enzyme when the substrate was the maize silage. Furthermore, 


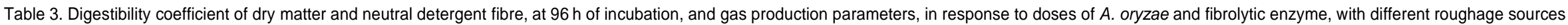

\begin{tabular}{|c|c|c|c|c|c|c|c|c|c|c|c|c|c|c|c|c|}
\hline \multirow[b]{2}{*}{ Item } & \multirow[b]{2}{*}{ A0 } & \multicolumn{2}{|c|}{ A. oryzae } & \multirow[b]{2}{*}{ A3 } & \multicolumn{5}{|c|}{ Fibrolytic enzyme } & \multirow[b]{2}{*}{ E } & \multicolumn{5}{|c|}{ Probabilities $(P)^{2}$} & \multirow{2}{*}{$\begin{array}{c}E \times A \times \\
R\end{array}$} \\
\hline & & $\mathrm{A} 1$ & A2 & & E0 & E1 & E2 & E3 & S.E.M. ${ }^{1}$ & & $A$ & $\mathrm{R}$ & $E \times R$ & $A \times R$ & $E \times A$ & \\
\hline \multicolumn{17}{|l|}{ Digestibility $^{3}$} \\
\hline IVDMD96 & 0.52 & 0.52 & 0.52 & 0.53 & 0.52 & 0.52 & 0.52 & 0.52 & 0.004 & 0.122 & 0.031 & 0.001 & 0.095 & 0.750 & 0.170 & 0.163 \\
\hline Maize silage & 0.59 & 0.59 & 0.59 & 0.60 & $0.59^{b}$ & $0.59^{a b}$ & $0.59^{a}$ & $0.60^{\mathrm{a}}$ & & - & - & - & - & - & - & - \\
\hline Sugarcane silage & 0.44 & 0.44 & 0.45 & 0.46 & $0.45^{\mathrm{b}}$ & $0.45^{\mathrm{b}}$ & $0.45^{\mathrm{b}}$ & $0.45^{\mathrm{b}}$ & & - & - & - & - & - & - & - \\
\hline IVNDFD96 & 0.32 & 0.32 & 0.32 & 0.34 & 0.32 & 0.32 & 0.27 & 0.27 & 0.005 & 0.082 & 0.001 & 0.001 & 0.091 & 0.816 & 0.160 & 0.274 \\
\hline Maize silage & 0.37 & 0.37 & 0.38 & 0.39 & $0.37^{b}$ & $0.37^{\mathrm{b}}$ & $0.37^{\mathrm{b}}$ & $0.39^{a}$ & & - & - & - & - & - & - & - \\
\hline Sugarcane silage & 0.26 & 0.27 & 0.27 & 0.28 & $0.27^{b}$ & $0.27^{\mathrm{b}}$ & $0.27^{\mathrm{b}}$ & $0.27^{b}$ & & - & - & - & - & - & - & - \\
\hline \multicolumn{17}{|l|}{ GP parameters ${ }^{4}$} \\
\hline$V_{f}(\mathrm{ml} / \mathrm{g} \mathrm{DM})$ & 176 & 179 & 175 & 201 & 173 & 185 & 186 & 187 & 3.3 & 0.011 & 0.001 & 0.001 & 0.388 & 0.010 & 0.534 & 0.901 \\
\hline Maize silage & $191^{\mathrm{b}}$ & $190^{\mathrm{b}}$ & $189^{b}$ & $202^{\mathrm{a}}$ & 187 & 194 & 195 & 195 & & - & - & - & - & - & - & - \\
\hline Sugarcane silage & $161^{\mathrm{c}}$ & $168^{b}$ & $162^{b}$ & $200^{\mathrm{a}}$ & 159 & 175 & 178 & 178 & & - & - & - & - & - & - & - \\
\hline$b(1 / h)$ & 0.02 & 0.02 & 0.02 & 0.02 & 0.02 & 0.02 & 0.02 & 0.02 & 0.001 & 0.165 & 0.143 & 0.001 & 0.404 & 0.551 & 0.073 & 0.772 \\
\hline Maize silage & 0.02 & 0.02 & 0.02 & 0.02 & 0.02 & 0.02 & 0.02 & 0.02 & & - & - & - & - & - & - & - \\
\hline Sugarcane silage & 0.02 & 0.02 & 0.02 & 0.01 & 0.02 & 0.02 & 0.02 & 0.02 & & - & - & - & - & - & - & - \\
\hline$c(1 / 2 \mathrm{~h})$ & -0.02 & -0.01 & -0.02 & 0.01 & -0.02 & -0.01 & -0.01 & -0.01 & 0.005 & 0.111 & 0.001 & 0.001 & 0.342 & 0.124 & 0.040 & 0.720 \\
\hline Maize silage & 0.01 & -0.01 & -0.01 & 0.01 & -0.01 & 0.01 & 0.01 & 0.01 & & - & - & - & - & - & - & - \\
\hline Sugarcane silage & -0.04 & -0.03 & -0.03 & 0.01 & -0.04 & -0.01 & -0.02 & -0.02 & & - & - & - & - & - & - & - \\
\hline$L(\mathrm{~h})$ & 1.9 & 2.0 & 1.8 & 2.2 & 2.3 & 1.9 & 1.9 & 1.9 & 0.14 & 0.071 & 0.111 & 0.001 & 0.996 & 0.451 & 0.181 & 0.574 \\
\hline Maize silage & 2.9 & 3.2 & 3.0 & 3.3 & 3.3 & 3.0 & 3.0 & 3.0 & & - & - & - & - & - & - & - \\
\hline Sugarcane silage & 1.0 & 0.8 & 0.7 & 1.2 & 1.2 & 0.8 & 0.8 & 0.8 & & - & - & - & - & - & - & - \\
\hline
\end{tabular}

Means within a row with different superscript letters differ.

Means highlighted in italics are the combination of roughage $X$ additive

Standard error mean.

E: fibrolytic enzyme; A: A. oryzae; R: roughage.

IVDMD: in vitro dry matter digestibility coefficient (96 $\mathrm{h}$ of incubation); IVNDFD: in vitro NDF digestibility coefficient ( $96 \mathrm{~h}$ ).

${ }^{4}$ Gas production parameters, obtained by the model of France et $a l .(1993) ; V_{f}$ : potential for gas production; $b$ and $c$ : constants fractional rates; $L$ : lag time. 
there was a linear increase in $V_{\mathrm{f}}$ in response to increasing enzyme doses $(P=0.011)$, regardless of the roughage $(173.1,184.8,186.4$ and $186.7 \mathrm{ml} / \mathrm{g}$ of DM, for E0, E1, E2 and E3, respectively). In addition, there was a trend of reduction of lag time in response to enzymatic treatment in both roughages $(2.23,1.90,1.90$ and $1.90 \mathrm{~h}$ for E0, E1, E2 and E3, respectively; $P=0.071)$.

For the cumulative gas production, it was observed that treatment with increasing doses of $A$. oryzae also increased gas production, but this effect was different according to the roughage (Table 4). In sugarcane silage, $A$. oryzae increased the gas production when compared to the control $(P=0.001)$, whereas the higher dosage resulted in the highest observed gas production value in all evaluated times, however there was no effect on gas production after $4 \mathrm{~h}$ of incubation. In maize silage, this effect was significant only in the highest dose of A. oryzae. Similarly, it was observed that enzymatic treatment increased gas produc- tion in both roughages $(P<0.051$, Table 4$)$.

In the methanogenesis bioassay, there was no significant effect of treatments on methane production parameters $(P>0.241$; Table $5)$. Similarly, there was no two-way interaction $\operatorname{effect}(P \geq$ 0.120 ) among treatments on IVDMD24 and IVNDFD24. Although there was no effect of enzyme and A. oryzae on IVD24 of DM and NDF, the degradation was higher $(P=0.001$; Table 2) in maize than sugarcane silage (Table 5; 0.454 v. 0.262 for IVDMD; and 0.196 v. 0.127 for IVNDFD, respectively).

A reduction in $\mathrm{N}-\mathrm{NH}_{3}$ concentration was observed in response to $A$. oryzae treatment $(P=0.049$; Table 6$)$, regardless of roughage $(15.4,14.7,14.6$ and $14.64 \mathrm{mg} / \mathrm{dl}$, for A0, A1, A2 and A3, respectively). In addition, the highest dose of $A$. oryzae (A3) increased the concentration of acetic acid, independently of the roughage $(23.38,23.36,23.18$ and 25.02, for A0, A1, A2 and A3, respectively; $P=0.031)$. No significant effect of the $A$. oryzae on the other fermentative parameters was observed $(P>0.305)$.

There was a trend $(P=0.087$; Table 6$)$ for $\mathrm{N}-\mathrm{NH}_{3}$ concentration reduction in response to fibrolytic enzyme treatment, however this effect was significant only for maize silage. In addition, there was a trend of increase in acetic acid concentration in response to the enzymatic treatment $(P=0.071)$, where the highest dose (E3) presented the highest value for this variable, regardless of the roughage $(23.6,22.9,23.4$ and $25.0 \mu \mathrm{M}$, for E0, E1, E2 and E3, respectively).

\section{Discussion}

The results of the current study indicate that live cultures of $A$. oryzae and fibrolytic enzyme are able to modulate the in vitro ruminal fermentation, decreasing $\mathrm{N}-\mathrm{NH}_{3}$ and improving acetic acid concentration and in vitro degradation of DM and NDF. However, there is no synergic effect among them, and the positive response to these additives was dependent on doses and type of roughage used. To our knowledge, this is the first study on the use of live cultures of $A$. oryzae in combination with fibrolytic enzyme in the modulation of in vitro ruminal fermentation, although previous studies have used these additives separately (Meale et al., 2014; Sun et al., 2014).

The potential for gas production in an in vitro assay is directly related to the chemical composition, especially fibrous content and structural polysaccharides (Musco et al., 2016). In this con- text, the degradability characteristics of roughage should be considered when evaluating the effect of additives on ruminal fibre digestibility. In the current study, additives increased gas production at all incubation times, regardless of roughage. This result observed for the A. oryzae is similar to others reported in the literature (Morgavi et al., 2004; Sun et al., 2014), where the microbial additive may increase fibrolytic activity by stimulating the growth of the rumen microorganisms. Aspergillus oryzae has a physical action on fibre due to the growth of mycelium and hyphae through the roughage, increasing bacterial access and colonization of the fibre fraction, increasing fibre digestibility (Giraldo et al., 2008). Furthermore, fungi can produce a range of enzymes, fibrolytic and amylolytic, and phytohormones that stimulate the activities of microorganisms, which can also promote improvements in fibre digestibility (Sher et al., 2017; Zayed, 2018). Similarly, the addition of fibrolytic enzyme may increase fibrolytic activity by stimulating the growth of ruminal microorganisms through the release of cell wall compounds (López-Aguirre et al., 2016).

Despite the increase in gas production observed in all incubation times, $A$. oryzae increased the in vitro NDF and DM digestibility, regardless of the type of roughage. The possible explanation for this could be the chemical composition of roughage, since the proportion of rumen potentially digestible NDF may affect the response to the addition of fibrolytic enzyme (Mendoza et al., 2014). Mendoza et al. (2014) describe that the addition of exogenous enzymes promotes improvements in the digestibility parameters of roughages that present a high propor- tion of potentially digestible fibre fraction. In the current study, the fibrolytic enzyme presents high xylanase activity, which may have acted in the most digestible fractions of sugarcane, altering or weakening the cell wall structure, without reflecting on the significant effect on in vitro NDF digestibility (Giraldo et al., 2008; Sakita et al., 2020).

As mentioned earlier, in the current study, our initial approach was that $A$. oryzae and exogenous fibrolytic enzyme would synergistically improve gas production and in vitro fibre degradation. That approach was based on the fact that the xylanases can hydrolyse xylan, increasing cellulose accessibility to the cellulase enzymes through increasing fibre swelling and fibre porosity (Gonçalves et al., 2015). When using these additives together, the presence of a diversity of enzymes together could reach a var-iety of substrates, increasing the fibre digestibility (Srinivas et al., 2008). So, as mentioned earlier, A. oryzae can produce a range of enzymes, including cellulose, and the supplementation with fibrolytic enzyme would substantially increase fibre degradability, once that xylan is one of the major mechanisms that limited the accessibility of the cellulase enzymes to the cellulose. However, in the current study, there is no synergic effect among them. A possible explanation would be related to the type of exogenous enzyme used. The supplementation of cellulases with xylanase can increase the rate and extent of cellulose hydrolysis ( $\mathrm{Hu}$ et al., 2011). However, it appears that the type of interaction between xylanase and cellulase enzymes is dependent on several factors, such as enzyme ratio and total enzyme loading (Jeoh et al., 2006; Zerva et al., 2020). Addressing this, Hu et al. (2011) observed a strong synergistic effect at low cellulase loading and when a high xylanase to cellulase ratio was used. Furthermore, Zayed et al. (2020) in an in vitro study reported that the simultan-eous use of inoculants containing fungal and bacterial strains, as asource of exogenous cellulolytic enzymes, increased the fibre digestibility of rice straw.

In this context, other factors may influence the results when using fibrolytic enzyme in order to modulate rumen fermentation, such as dose-response effect, as well as the types of enzymes. The main fibrolytic enzymes are cellulases and xylanases, which act 
Table 4. Cumulative gas production (GP expressed in $\mathrm{ml} / \mathrm{g} \mathrm{DM}$ ) in response to doses of $A$. oryzae and fibrolytic enzyme

\begin{tabular}{|c|c|c|c|c|c|c|c|c|c|c|c|c|c|c|c|c|}
\hline \multirow[b]{2}{*}{ Item } & \multirow[b]{2}{*}{$\mathrm{A} 0$} & \multicolumn{2}{|c|}{ A. oryzae } & \multicolumn{6}{|c|}{ Fibrolytic enzyme } & \multicolumn{7}{|c|}{ Probabilities $(P)^{2}$} \\
\hline & & $\mathrm{A} 1$ & A2 & A3 & E0 & E1 & E2 & E3 & S.E.M. ${ }^{1}$ & $E$ & A & R & $E \times R$ & $A \times R$ & $E \times A$ & $E \times A \times R$ \\
\hline $4 \mathrm{~h}$ & 7.0 & 6.7 & 7.1 & 7.2 & 5.9 & 7.2 & 7.1 & 7.7 & 0.38 & 0.001 & 0.589 & 0.001 & 0.803 & 0.121 & 0.841 & 0.989 \\
\hline Maize silage & 6.5 & 5.4 & 6.0 & 5.9 & 4.8 & 6.3 & 6.2 & 6.5 & & - & - & - & - & - & - & - \\
\hline Sugarcane silage & 7.4 & 7.9 & 8.2 & 8.5 & 7.0 & 8.0 & 8.1 & 9.0 & & - & - & - & - & - & - & - \\
\hline $8 \mathrm{~h}$ & 16.9 & 16.8 & 17.2 & 19.5 & 15.5 & 17.8 & 18.4 & 18.7 & 0.70 & 0.001 & 0.001 & 0.001 & 0.964 & 0.001 & 0.942 & 0.865 \\
\hline Maize silage & $17.6^{\mathrm{b}}$ & $15.3^{b}$ & $16.1^{\mathrm{b}}$ & $17.6^{a}$ & 14.6 & 16.8 & 17.3 & 17.9 & & - & - & - & - & - & - & - \\
\hline Sugarcane silage & $16.2^{\mathrm{c}}$ & $18.3^{\mathrm{b}}$ & $18.2^{\mathrm{b}}$ & $21.4^{\mathrm{a}}$ & 16.4 & 18.8 & 19.5 & 19.5 & & - & - & - & - & - & - & - \\
\hline $12 \mathrm{~h}$ & 28.7 & 29.4 & 30.1 & 35.4 & 28.2 & 31.3 & 31.6 & 32.4 & 0.74 & 0.001 & 0.001 & 0.001 & 0.620 & 0.001 & 0.664 & 0.886 \\
\hline Maize silage & $35.2^{b}$ & $33.4^{b}$ & $34.0^{\mathrm{b}}$ & $37.8^{\mathrm{a}}$ & 32.8 & 35.6 & 35.3 & 36.8 & & - & - & - & - & - & - & - \\
\hline Sugarcane silage & $22.2^{\mathrm{c}}$ & $25.4^{\mathrm{b}}$ & $26.1^{\mathrm{b}}$ & $32.9^{a}$ & 23.5 & 27.1 & 27.9 & 28.1 & & - & - & - & - & - & - & - \\
\hline $18 \mathrm{~h}$ & 43 & 45 & 46 & 54 & 44 & 48 & 47 & 49 & 1.2 & 0.001 & 0.001 & 0.001 & 0.531 & 0.001 & 0.739 & 0.981 \\
\hline Maize silage & $56^{b}$ & $56^{b}$ & $57^{b}$ & $63^{a}$ & 55 & 59 & 57 & 61 & & - & - & - & - & - & - & - \\
\hline Sugarcane silage & $29^{c}$ & $34^{b}$ & $36^{\mathrm{b}}$ & $46^{a}$ & 33 & 36 & 37 & 38 & & - & - & - & - & - & - & - \\
\hline $24 \mathrm{~h}$ & 54 & 57 & 58 & 67 & 56 & 60 & 59 & 62 & 1.6 & 0.011 & 0.001 & 0.001 & 0.473 & 0.001 & 0.828 & 0.940 \\
\hline Maize silage & $72^{b}$ & $72^{b}$ & $73^{b}$ & $79^{a}$ & 71 & 75 & 72 & 77 & & - & - & - & - & - & - & - \\
\hline Sugarcane silage & $37^{c}$ & $41^{\mathrm{b}}$ & $44^{\mathrm{b}}$ & $56^{a}$ & 41 & 44 & 46 & 46 & & - & - & - & - & - & - & - \\
\hline $48 \mathrm{~h}$ & 97 & 100 & 102 & 113 & 99 & 103 & 103 & 106 & 2.4 & 0.044 & 0.001 & 0.001 & 0.444 & 0.042 & 0.666 & 0.791 \\
\hline Maize silage & $120^{\mathrm{b}}$ & $120^{\mathrm{b}}$ & $122^{b}$ & $129^{a}$ & 118 & 124 & 121 & 128 & & - & - & - & - & - & - & - \\
\hline Sugarcane silage & $74^{c}$ & $79^{b c}$ & $81^{\mathrm{b}}$ & $97^{a}$ & 80 & 82 & 85 & 85 & & - & - & - & - & - & - & - \\
\hline $96 \mathrm{~h}$ & 145 & 147 & 147 & 160 & 145 & 150 & 150 & 153 & 2.8 & 0.052 & 0.001 & 0.001 & 0.579 & 0.363 & 0.921 & 0.872 \\
\hline Maize silage & 166 & 167 & 168 & 176 & 164 & 171 & 168 & 174 & & - & - & - & - & - & - & - \\
\hline Sugarcane silage & 123 & 126 & 127 & 143 & 126 & 129 & 133 & 132 & & - & - & - & - & - & - & - \\
\hline
\end{tabular}

Means within a row with different superscript letters differ.

Means highlighted in italics are the combination of roughage $X$ additive

'SE: fibrolytic enzyme; A: A. oryzae; R: roughage. 
Table 5. Effect of $A$. oryzae and fibrolytic enzyme on digestibility and methane emission evaluated by in vitro methanogenesis bioassay

\begin{tabular}{|c|c|c|c|c|c|c|c|c|c|c|c|c|c|c|c|c|}
\hline \multirow[b]{2}{*}{ Item } & \multirow[b]{2}{*}{ A0 } & \multicolumn{2}{|c|}{ A. oryzae } & \multirow[b]{2}{*}{ A3 } & \multicolumn{4}{|c|}{ Fibrolytic enzyme } & \multirow[b]{2}{*}{ S.E.M. ${ }^{a}$} & \multirow[b]{2}{*}{$E$} & \multicolumn{5}{|c|}{ Probabilities $(P)^{\mathrm{b}}$} & \multirow{2}{*}{$\begin{array}{c}E \times A \times \\
R\end{array}$} \\
\hline & & $\mathrm{A} 1$ & A2 & & E0 & E1 & E2 & E3 & & & A & $\mathrm{R}$ & $E \times R$ & $A \times R$ & $E \times A$ & \\
\hline \multicolumn{17}{|l|}{ Digestibilityc } \\
\hline IVDMD24 & 0.36 & 0.36 & 0.36 & 0.36 & 0.36 & 0.36 & 0.36 & 0.36 & 0.004 & 0.993 & 0.687 & 0.001 & 0.222 & 0.120 & 0.582 & 0.431 \\
\hline Maize silage & 0.46 & 0.45 & 0.45 & 0.46 & 0.45 & 0.46 & 0.45 & 0.45 & & - & - & - & - & - & - & - \\
\hline Sugarcane silage & 0.26 & 0.27 & 0.26 & 0.26 & 0.26 & 0.26 & 0.27 & 0.26 & & - & - & - & - & - & - & - \\
\hline IVNDFD24 & 0.16 & 0.16 & 0.16 & 0.17 & 0.16 & 0.16 & 0.16 & 0.16 & 0.003 & 1.000 & 0.994 & 0.001 & 1.000 & 0.991 & 0.131 & 0.393 \\
\hline Maize silage & 0.20 & 0.20 & 0.20 & 0.20 & 0.19 & 0.20 & 0.20 & 0.20 & & - & - & - & - & - & - & - \\
\hline Sugarcane silage & 0.13 & 0.13 & 0.13 & 0.13 & 0.13 & 0.13 & 0.13 & 0.13 & & - & - & - & - & - & - & - \\
\hline \multicolumn{17}{|l|}{ Methanogenesis ${ }^{d}$} \\
\hline GP24 (ml/g IVDMD) & 259 & 260 & 274 & 284 & 262 & 263 & 269 & 282 & 14.1 & 0.478 & 0.241 & 0.447 & 0.985 & 0.501 & 0.891 & 0.921 \\
\hline Maize silage & 268 & 252 & 268 & 272 & 260 & 258 & 268 & 275 & & - & - & - & - & - & - & - \\
\hline Sugarcane silage & 249 & 267 & 279 & 295 & 263 & 268 & 271 & 289 & & - & - & - & - & - & - & - \\
\hline $\mathrm{CH}_{4}$ content $(\%)$ & 5.9 & 5.8 & 5.7 & 5.9 & 5.7 & 5.9 & 5.9 & 5.7 & 0.19 & 0.666 & 0.604 & 0.511 & 0.112 & 0.123 & 0.672 & 0.473 \\
\hline Maize silage & 6.1 & 5.8 & 5.4 & 5.8 & 5.5 & 5.9 & 6.1 & 5.5 & & - & - & - & - & - & - & - \\
\hline Sugarcane silage & 5.8 & 5.7 & 6.0 & 6.0 & 5.9 & 5.8 & 5.7 & 5.9 & & - & - & - & - & - & - & - \\
\hline $\begin{array}{l}\text { Adjusted } \mathrm{CH}_{4}(\mathrm{ml} / \mathrm{g} \\
\text { IVDMD) }\end{array}$ & 13 & 13 & 13 & 15 & 13 & 13 & 14 & 14 & 1.0 & 0.700 & 0.312 & 0.242 & 0.340 & 0.184 & 1.000 & 0.774 \\
\hline Maize silage & 14 & 12 & 12 & 14 & 12 & 13 & 14 & 13 & & - & - & - & - & - & - & - \\
\hline Sugarcane silage & 12 & 13 & 14 & 15 & 13 & 14 & 13 & 15 & & - & - & - & - & - & - & - \\
\hline Net $\mathrm{CH}_{4}(\mathrm{ml})$ & 5.7 & 5.1 & 5.2 & 5.9 & 5.1 & 5.6 & 5.7 & 5.5 & 0.46 & 0.541 & 0.293 & 0.001 & 0.151 & 0.112 & 0.911 & 0.602 \\
\hline Maize silage & 7.3 & 6.1 & 5.6 & 6.7 & 5.7 & 6.7 & 7.3 & 6.1 & & - & - & - & - & - & - & - \\
\hline Sugarcane silage & 4.1 & 4.1 & 4.7 & 5.0 & 4.4 & 4.5 & 4.2 & 4.9 & & - & - & - & - & - & - & - \\
\hline $\mathrm{CH}_{4}$ efficiency (ml/100 GP) & 5.1 & 4.9 & 4.8 & 5.1 & 4.8 & 5.1 & 5.1 & 4.9 & 0.25 & 0.601 & 0.461 & 0.364 & 0.113 & 0.140 & 0.791 & 0.581 \\
\hline Maize silage & 5.3 & 4.9 & 4.4 & 5.0 & 4.6 & 5.1 & 5.3 & 4.6 & & - & - & - & - & - & - & - \\
\hline Sugarcane silage & 5.0 & 4.8 & 5.2 & 5.2 & 5.1 & 5.1 & 4.8 & 5.2 & & - & - & - & - & - & - & - \\
\hline
\end{tabular}

Means highlighted in italics are the combination of roughage $X$ additive

aStandard error of the mean.

E: fibrolytic enzyme, A: A. oryzae, R: roughage.

"IVDMD: in vitro dry matter digestibility coefficient (24 $\mathrm{h}$ of incubation); IVNDFD: in vitro NDF digestibility coefficient $(24 \mathrm{~h})$.

${ }^{\circ} \mathrm{GP} 24$ : gas production per gram of degraded dry matter, after $24 \mathrm{~h}$ of incubation; methane $\left(\mathrm{CH}_{4}\right)$ efficiency $=\left[100 \times\left(\right.\right.$ adjusted $\left.\mathrm{CH}_{4} / \mathrm{GP}\right)$. 
Table 6. Fermentative profile in response to the treatment with Aspergillus oryzae and fibrolytic enzyme

\begin{tabular}{|c|c|c|c|c|c|c|c|c|c|c|c|c|c|c|c|c|}
\hline \multirow[b]{2}{*}{ Item } & \multirow[b]{2}{*}{ A0 } & \multicolumn{2}{|c|}{ A. oryzae } & \multicolumn{6}{|c|}{ Fibrolytic enzyme } & \multicolumn{7}{|c|}{ Probabilities $(P)^{2}$} \\
\hline & & $\mathrm{A} 1$ & A2 & A3 & E0 & E1 & E2 & E3 & S.E.M. ${ }^{1}$ & $E$ & A & $\mathrm{R}$ & $E \times R$ & $A \times R$ & $E \times A$ & $E \times A \times R$ \\
\hline $\mathrm{N}-\mathrm{NH}_{3}(\mathrm{mg} / \mathrm{dl})^{3}$ & 15.4 & 14.7 & 14.6 & 14.6 & 15.2 & 14.8 & 14.6 & 14.8 & 0.45 & 0.271 & 0.049 & 0.682 & 0.087 & 1.000 & 0.200 & 0.988 \\
\hline Maize silage & 15.4 & 14.7 & 14.7 & 14.7 & $15.4^{\mathrm{a}}$ & $14.8^{\mathrm{b}}$ & $14.7^{\mathrm{b}}$ & $14.7^{\mathrm{b}}$ & & - & - & - & - & - & - & - \\
\hline Sugarcane silage & 15.3 & 14.7 & 14.5 & 14.5 & $15.0^{\mathrm{b}}$ & $14.7^{b}$ & $14.5^{\mathrm{b}}$ & $14.8^{b}$ & & - & - & - & - & - & - & - \\
\hline Acetic acid (mM) & 23.4 & 23.3 & 23.2 & 25.0 & 23.5 & 23.0 & 23.4 & 25.0 & 0.87 & 0.071 & 0.031 & 0.001 & 0.522 & 0.391 & 0.781 & 0.852 \\
\hline Maize silage & 24.8 & 25.1 & 24.9 & 25.7 & 24.3 & 24.6 & 25.0 & 26.6 & & - & - & - & - & - & - & - \\
\hline Sugarcane silage & 21.9 & 21.5 & 21.4 & 24.3 & 22.7 & 21.3 & 21.7 & 23.3 & & - & - & - & - & - & - & - \\
\hline Propionic acid (mм) & 16.2 & 16.2 & 16.5 & 16.3 & 16.0 & 16.0 & 16.4 & 16.8 & 0.57 & 0.482 & 0.971 & 0.001 & 0.964 & 0.394 & 0.481 & 0.483 \\
\hline Maize silage & 17.2 & 17.4 & 18.3 & 17.3 & 17.3 & 17.3 & 17.4 & 18.1 & & - & - & - & - & - & - & - \\
\hline Sugarcane silage & 15.2 & 14.9 & 14.6 & 15.2 & 14.7 & 14.6 & 15.3 & 15.4 & & - & - & - & - & - & - & - \\
\hline Butyric acid (mм) & 5.8 & 5.7 & 5.8 & 5.6 & 5.6 & 5.7 & 5.7 & 5.9 & 0.21 & 0.573 & 0.533 & 0.001 & 0.800 & 0.243 & 0.671 & 0.881 \\
\hline Maize silage & 6.7 & 6.5 & 7.0 & 6.3 & 6.5 & 6.7 & 6.5 & 6.8 & & - & - & - & - & - & - & - \\
\hline Sugarcane silage & 4.9 & 4.9 & 4.7 & 4.8 & 4.7 & 4.7 & 5.0 & 5.0 & & - & - & - & - & - & - & - \\
\hline Isobutyric acid (mM) & 0.6 & 0.6 & 0.6 & 0.6 & 0.6 & 0.6 & 0.6 & 0.6 & 0.08 & 0.921 & 0.982 & 0.010 & 0.861 & 0.960 & 0.991 & 1.000 \\
\hline Maize silage & 0.7 & 0.7 & 0.7 & 0.7 & 0.6 & 0.7 & 0.7 & 0.7 & & - & - & - & - & - & - & - \\
\hline Sugarcane silage & 0.5 & 0.5 & 0.5 & 0.5 & 0.5 & 0.5 & 0.6 & 0.5 & & - & - & - & - & - & - & - \\
\hline Valeric acid (mм) & 1.3 & 1.3 & 1.3 & 1.2 & 1.2 & 1.3 & 1.3 & 1.3 & 0.06 & 0.305 & 0.599 & 0.001 & 0.901 & 0.871 & 0.911 & 0.791 \\
\hline Maize silage & 1.7 & 1.6 & 1.7 & 1.6 & 1.5 & 1.6 & 1.7 & 1.7 & & - & - & - & - & - & - & - \\
\hline Sugarcane silage & 1.0 & 0.9 & 0.9 & 0.9 & 0.9 & 0.9 & 0.9 & 1.0 & & - & - & - & - & - & - & - \\
\hline Isovaleric acid (mм) & 1.0 & 1.0 & 1.0 & 1.0 & 1.0 & 1.0 & 1.0 & 1.0 & 0.06 & 0.960 & 0.999 & 0.001 & 1.000 & 0.900 & 1.000 & 1.000 \\
\hline Maize silage & 1.1 & 1.1 & 1.1 & 1.1 & 1.1 & 1.1 & 1.1 & 1.1 & & - & - & - & - & - & - & - \\
\hline Sugarcane silage & 0.9 & 0.9 & 0.9 & 0.9 & 0.9 & 0.9 & 0.9 & 0.9 & & - & - & - & - & - & - & - \\
\hline
\end{tabular}

Means within a row with different superscript letters differ.

Means highlighted in italics are the combination of roughage $\mathrm{X}$ additive.

'Standard error mean.

2E: fibrolytic enzyme; A: A. oryzae; R: roughage.

${ }^{3} \mathrm{~N}-\mathrm{NH} 3$ : ammoniacal nitrogen. 
mainly in the degradation of cellulose and hemicellulose, respectively. Considering the high xylanase activity of the exogenous enzyme used in the present study, this could explain the result observed for IVDMD96 in response to the enzymatic treatment, which was significant only for maize silage, due to the fact that sugarcane silage has a lower hemicellulose content, justifying the lesser effect of the fibrolytic enzyme on this roughage when compared to maize silage. López-Aguirre et al. (2016), when evaluating different types of fibrolytic enzymes (cellulase, xylanase and the combination of both) at different dosages, observed that cellulase presented the best fermentative kinetics parameters for gas production, since the highest dose of fibrolytic enzyme with xylanase activity reduced gas production at all incubation times. Thus, the high dosage of xylanase may have affected the binding of enzymes to receptors present in the substrate, and consequently reducing the binding of fibrolytic microorganisms to fibre (Beauchemin et al., 2001). However, Togtokhbayar et al. (2015) described that the addition of fibrolytic enzyme with high xyla- nase activity at different doses in an in vitro assay using wheat straw as a substrate promoted increased gas production at all eval-uated incubation times. These results demonstrate that the chem-ical composition of roughage affects exogenous enzyme responses, as well as the dose and type of enzyme used.

There are indications that enzymes produced by fungi, such as the $A$. oryzae, may act on the degradation of lignocellulosic materials, but a longer ruminal retention time is required for the effective action of fibrolytic microorganisms (Kumar et al., 2009). Thus, it is assumed that the addition of exogenous fibrolytic enzymes may promote lag time reduction, since enzymes can degrade substrate complex carbohydrates to simple forms at an early stage of fermentation, thus allowing rapid growth of bacterial population, and consequent colonization and fibre fermentation (López-Aguirre et al., 2016). In the current study, both additives increased the $V_{\mathrm{f}}$. However, for $A$. oryzae, this effect was dependent on the roughage source. In addition, A. oryzae showed higher lag time, in both roughages, when compared to the fibrolytic enzyme $(3.15 v .2 .96 \mathrm{~h}$ for maize silage, and $0.89 v .0 .84 \mathrm{~h}$ for sugarcane silage), which indicates that $A$. oryzae needs more time for its development to promote significant improvementsin fibre digestibility. Moreover, the lack of results from the A. ory-zae on gas production after $4 \mathrm{~h}$ of incubation may reinforce this hypothesis.

In this context, a way to potentiate the effect of the fungus would be to increase the number of viable spores, by increasing the doses of $A$. oryzae, which could mitigate the effect of lag time. It is assumed that the increase in the number of viablespores would result in greater adherence to the fibrous particle, increasing the surface area available for fibrolytic activity and, consequently, enhancing the fibre digestibility over the incubationtime (Sjaastad et al., 2010). This could justify the better results of gas production potential, as well as for digestibility parameters, for treatments with the highest dose of $A$. oryzae.

In the current study, $A$. oryzae reduced ammonia-N content regardless of roughage, whereas fibrolytic enzyme reduced ammonia-N only in maize silage. Moreover, either enzyme or A. oryzae increased acetate concentration. Acetate productionis related to the action of fibrolytic microorganisms that ferment carbohydrates to acetate. These microorganisms use ammonia-N as the source of nitrogen (Russell and Wilson, 1996), which may justify the effects of additives in both variables. Thus, the additives stimulated the fibrolytic microbiota, increasing the in vitro NDF digestibility, and increasing the acetate as a final fermentation product. In addition, this result can be correlated to the increase in gas production with the $A$. oryzae treatment, and the highest values were observed at the highest $A$. oryzae dose, which maybe explained by the higher number of spores in this treatment, resulting in a higher fibre degradation.

\section{Conclusion}

The additives did not have a synergistic effect on gas production and digestibility, contrary to the initial hypothesis, that the additives would synergistically enhance the fibre digestibility. However, the results of the current study indicate that doses of A. oryzae and fibrolytic enzyme are able to modulate the in vitro ruminal fermentation, decreasing $\mathrm{N}-\mathrm{NH}_{3}$ and improving acetic acid concentration and in vitro degradation of DM and NDF.

Financial support. This study was funded by São Paulo Research Foundation - FAPESP (Number 2017/11537-6).

\section{Conflict of interest. None.}

Ethical standards. All applicable international, national and/or institutional guidelines for the care and use of animals were followed (University of São Paulo Animal Bioethics Committee, protocol number 7551070817).

\section{References}

Abid K, Jabri J, Beckers Y, Yaich H, Malek A, Rekhis $\mathrm{J}$ and Kamoun $M$ (2019) Influence of adding fibrolytic enzymes on the ruminal fermentationof date palm by-products. Archives Animal Breeding 62, 18.

AOAC Association of Official Analytical Chemists (2000) Official Methods of Analysis of the Association of the Analytical Chemists, 17th Edn. Arlington, VA, USA: AOAC Association of Official Analytical Chemists.

Balieiro Neto G, Ferrari Junior E, Nogueira JR, Possenti R, Valdinei

Tadeu Paulino VT and Bueno MS (2009) Fermentation losses, chemical com- position, aerobic stability and apparent digestibility of sugarcane ensiling with chemical and microbial additives. Pesquisa Agropecuária Brasileira44, 621-630.

Beauchemin KA, Morgavi DP, McAllister TA, Yang WZ and Rode LM (2001) The use of enzymes in ruminant diets. In Garnsworthy PC and Wiseman J (eds), Recent Advances in Animal Nutrition. Loughborough, UK: Nottingham University Press, pp. 297-322.

Broderick GA and Kang JH (1980) Automated simultaneous determination of ammonia and total amino acids in ruminal fluid and in vitro media. Journal of Dairy Science 63, 64-75.

Bueno ICS, Cabral Filho SLS, Gobbo SP, Louvandini H, Vitti DMSS and Abdalla AL (2005) Influence of inoculum source in a gas production method. Animal Feed Science and Technology 123, 95-105.

Casali AO, Detmann E, Valadares Filho SC, Pereira JC, Henriques LT,Freitas SG and Paulino MF (2008) Influence of incubation time and par- ticles size on indigestible compounds contents in cattle feeds and feces obtained by in situ procedures. Revista Brasileira de Zootecnia 37, 335-342. Cunha LP, Casciatori FP, Vicente IV, Garcia RL and

Thoméo JC (2020)Metarhizium anisopliae conidia production in packed-bed bioreactor using rice as substrate in successive cultivations.

Process Biochemistry 97, 104-111.

Detmann E, Paulino MF, Zervoudakis JT, Valadares Filho SC, Euclydes RF, Lana RP and Queiroz DS (2001) Chromium and internal markers in intake determination by crossbred steers, supplemented at pasture. Revista Brasileira de Zootecnia 30, 1600-1609.

Elghandour MMY, Kholif AE, Hernandez J, Mariezcurrena MD, Lopez S, Camacho LM, Marquez O and Salem AZM (2016) Influence of the add- ition of exogenous xylanase with or without preincubation on the in vitro ruminal fermentation of three fibrous feeds, Czech. Journal of Animal Science 61, 262-272. 
Erwin ES, Marco GJ and Emery EM (1961) Volatile fatty acid analyses of blood and rumen fluid by gas chromatography. Journal of Dairy Science 44, 1768-1771.

FASS (1999) Guide for the Care and Use of Agricultural Animals in Agricultural Research and Teaching. Savoy, IL, USA: Federation of Animal Sciences Societies.

France J, Dhanoa MS and Theodorou MK (1993) A model to interpret gas accumulation profiles with in vitro degradation of ruminants feeds. Journal of Theoretical Biology 163, 99-111.

Frassatto PAC, Casciatori FP, Thoméo JC, Gomes E, Boscolo M and Silva R (2020) Fungal cellulases: production by solid-state cultivation in packedbed bioreactor using solid agro-industrial by-products as substrates and applica-tion for hydrolysis of sugarcane bagasse. Semina: Ciências Agrárias 41, 2097-2116.

Gandra JR, Miranda JA, Goes RHTB, Takiya CS, Del Valle TA, Oliveira ER, Freitas-Junior JE, Gandra ERS, Araki HMC and

Santos ALAV (2017) Fibrolytic enzyme supplementation through ruminal bolus on eating behav-ior, nutrient digestibility and ruminal fermentation in Jersey heifers fed either corn silage- or sugarcane silage-based diets. Animal Feed Scienceand Technology 231, 29-37.

Getachew G, Makkar HPS and Becker K (2002) Tropical browses contents of phenolics compounds, in vitro gas production and stoichiometric relation-ship between short chain fatty acid an in vitro gas production. Journal of Agricultural Science 139, 341-352.

Giraldo LA, Tejido ML, Ranilla MJ and Carro MD (2008) Effects of exogen- ous fibrolytic enzymes on in vitro ruminal fermentation of substrates with different forage:concentrate ratios. Animal Feed Science and Technology 141, 306-325.

Gonçalves GAL, Takasugia Y, Jiaa L, Moria Y, Nodab S, Tanakac T, Ichinosed $\mathrm{H}$ and Kamiyaa N (2015) Synergistic effect and application of xylanases as accessory enzymes to enhance the hydrolysis of pretreated bagasse. Enzyme and Microbial Technology 72, 16-24.

Grzegorczyk M, Kancelista A, Łaba W, Piegza M and Witkowska D (2018)The effect of lyophilization and storage time on the survival rate and hydro-lytic activity of Trichoderma strains. Folia Microbiologica 63, 433441.

Hu J, Arantes V and Saddler JN (2011) The enhancement of enzymatic hydroly-sis of lignocellulosic substrates by the addition of accessory enzymes such as xylanase: is it an additive or synergistic effect? Biotechnology for Biofuels 4, 36. Jeoh T, Wilson DB and Walker LP (2006) Effect of cellulase mole fractionand cellulose recalcitrance on synergism in cellulose Biotechnology Progress 22, 270-277.

$$
\text { hydrolysis and binding. }
$$

Kim HS, Ahn BS, Chung SG, Moon YH, Ha JK, Seo IJ, Ahn BH and Lee SS (2006) Effect of yeast culture, fungal fermentation extract and non-ionic surfactant on performance of Holstein cows during transition period. Animal Feed Science and Technology 126, 23-29.

Kumar P, Barrett DM, Delwiche MJ and Stroeve P (2009) Methods for pre- treatment of lignocellulosic biomass for efficient hydrolysis and biofuel pro-duction. Industrial and Engineering Chemistry Research 48, 37133729.

Latif MR, Zahran SM, Ahmed MH, Zeweil HS and Sallam SMA (2014) Effect of feeding Saccharomyces cerevisiae and/or Aspergillus oryzae on nutrient utilization and rumen fermentation characteristics of sheep. Alexandria Journal of Agricultural Research 59, 121-127.

López-Aguirre D, Hernández-Meléndez J, Rojo R, Sánchez-Dávila F, López-Villalobos N, Salem Abdel-Fattah ZM, Vázquez-Armijo JF, RuízS and Joaquin S (2016) In vitro gas production kinetics and degradability of a diet for growing lambs: effect of fibrolytic enzyme products at differentdose levels. Italian Journal of Animal Science 15, 453-460.

Mauricio RM, Mould FL, Dhanoa MS, Owen E, Channa KS and

TheodorouMK (1999) A semi-automated in vitro gas production technique for rumin- ant feedstuff evaluation. Animal Feed Science and Technology
79, 321-330. Meale SJ, Beauchemin KA, Hristov AN, Chaves AV and

Mcallister TA (2014)

Board-invited review: opportunities and challenges in using exogenous enzymes to improve ruminant production. Journal of Animal Science 92, 427-442.

Mendoza GD, Loera-Corral O, Plata-Pérez FX, Hernández-García

PA and Ramírez-Mella M (2014) Considerations on the use of exogenous fibrolytic enzymes to improve forage utilization. The Scientific World Journal 2014, 247437. 
Mertens DR (2000) Physical effective NDF and its use in formulating dairy rations. In Hall MB, Harris Jr B and Haskins B (eds), Florida Ruminant Nutrition Symposium. Best Western, Gainesville, FL: University of Florida, pp. 142-160.

Mertens DR (2002) Gravimetric determination of amylase-treated neutral detergent fiber in feeds with refluxing in beaker or crucibles: collaborative study. Journal of AOAC International 85, 1217-1240.

Morgavi DP, Beauchemin KA, Nsereko VL, Rode LM, McAllister TA and Wang Y (2004) Trichoderma enzymes promote Fibrobacter succinogenes $\mathrm{S} 85$ adhesion to, and degradation of, complex substrates but not pure cellu-lose. Journal of the Science of Food and Agriculture 84, 1083-1090.

Musco N, Koura IB, Tudisco R, Awadjihe G, Adjolohoun S, Cutrignelli MI, Mollica MP, Houinato M, Infascelli F and Calabro $S$ (2016) Nutritional characteristics of forage grown in south of Benin. Asian-Australasian Journal of Animal Sciences 29, 51-61.

Onodera R and Henderson C (1980) Growth factors of bacterial origin for the culture of the rumen oligotrichprotozoon, Entodinium caudatum. Journal ofApplied Bacteriology 48, 125-134.

Russell JB and Wilson DB (1996) Why are ruminal cellulolytic bacteria unable to digest cellulose at low pH? Journal of Dairy Science 79, 15031509.

Sakita GZ, Bompadre TFV, Dineshkumar D, Lima PMT, Abdalla Filho AL, Campioni TS, Oliva Neto $\mathrm{P}$, Bremer Neto $\mathrm{H}$, Louvandini $\mathrm{H}$ and AbdallaAL (2020) Fibrolytic enzymes improving in vitro rumen degradability of tropical forages. Journal of Animal Physiology and Animal Nutrition 104, 1267-1276.

Sallam S, Bueno I, Nasser ME and Abdalla AL (2010) Effect of eucalyptus (Eucalyptus citriodora) fresh or residue leaves on methane emission in vitro. Italian Journal of Animal Science 9, 299-303.

Santos KC, Carvalho FFR, Carriero MM, Magalhães ALR, Batista AMV, Fagundes GM and Bueno ICS (2020) Use of different carbohydrate sources associated with urea and implications for in vitro fermentation and rumen microbial populations. Animal Production Science 60, 1028-1038.

Sher H, Faheem M, Ghani A, Mehmood R, Rehman H and Bokhari SAI (2017) Optimization of cellulase enzyme production from Aspergillus ory- zae for industrial applications. World Journal of Biology and Biotechnology 2, 155-158.

Sjaastad ØV, Hove K and Sand O (2010) Physiology of Domestic Animals. Oslo, Norway: Scandinavian Veterinary Press.

Sosa A, Galindo J, Tejido ML, Díaz A, Martínez ME, Saro C, Carro MD and Ranilla MJ (2011) Effects of Aspergillus oryzae on in vitro ruminal fermen- tation. In Ranilla MJ, Carro MD, Ben Salem H and Morand-Fehr $\mathrm{P}$ (eds), Challenging Strategies to Promote the Sheep and Goat Sector in the Current Global Context. Zaragoza, ESP: CIHEAM/CSIC, Universidad de León, FAO, Options Méditerranéennes, pp. 175-179.

Srinivas B, Chaturvedi OH, Malik R and Asgar M (2008) Effect of enzyme to substrate ratio of exogenous fibrolytic and protease enzymes on in vitro gasproduction kinetics. Indian Journal of Small Ruminants 14, 181-190.

Sun H, Wu YM, Wang YM, Liu JX and Myung KH (2014) Effects of Aspergillus oryzae culture and 2-hydroxy-4-(methylthio)-butanoic acid on in vitro rumen fermentation and microbial populations between different roughage sources. Asian-Australasian Journal of Animal Sciences 27, 1285-1292.

Sun H, Wu Y, Wang Y, Wang C and Liu J (2017) Effects of addition of Aspergillus oryzae culture and 2-hydroxyl-4-(methylthio) butanoic acid on milk performance and rumen fermentation of dairy cows. Animal Science Journal 88, 602-609.

Theodorou MK, Williams BA, Dhanoa MS, McAllan AB and France $\mathrm{J}$ (1994). A simple gas production method using a pressure transducer to determine the fermentation kinetics of ruminant feeds. Animal Feed Science and Technology 48, 185-197.

Tirado-González DN, Miranda-Romero LA, Ruíz-Flores A, MedinaCuéllar SE, Ramírez-Valverde R and Tirado-Estrada G (2018) Meta-analysis: effects of exogenous fibrolytic enzymes in ruminant diets. Journal of Applied Animal Research 46, 771-783.

Togtokhbayar N, Cerrillo MA, Rodriguez GB, Elghadour MMY, Salem AZM, Urankhaich C, Jigjidpurev S, Odongo NE and Kholif AD (2015) 
Effect of exogenous xylanase on rumen in vitro gas production and degradability of wheat straw. Animal Science Journal 86, 765-771.

Tricarico JM, Abney MD, Galyean ML, Rivera JD, Hanson KC, Mcleod KRand Harmon DL (2007) Effects of a dietary Aspergillus oryzae extract con- taining alpha-amylase activity on performance and carcass characteristics offinishing beef cattle. Journal of Animal Science 85, 802811.

Van Soest PJ and Robertson JB (1985) Analysis of Forages and Fibrous Foods.Ithaca, USA: Cornell University.

Zayed MS (2018) Enhancement the feeding value of rice straw as animal fodder through microbial inoculants and physical treatments.
International Journal of Recycling of Organic Waste in Agriculture 7, 117124.

Zayed MS, Szumacher-Strabel M, El-Fattah DAA, Madkour MA, Gogulski M, Strompfová V, Cieślak A and El-Bordeny NE (2020). Evaluation of cel- lulolytic exogenous enzyme-containing microbial inoculants as feed addi- tives for ruminant rations composed of low-quality roughage. The Journal of Agricultural Science 158, 326-338.

Zerva A, Pentari C, Grisel S, Berrin JG and Topakas E (2020) A new syner- gistic relationship between xylan-active LPMO and xylobiohydrolase to tackle recalcitrant xylan. Biotechnology for Biofuels $13,142$. 